\title{
PROGRAM PEMBERDAYAAN MASYARAKAT KURANG MAMPU DESA MONTONG GAMANG DALAM PENGELOLAAN DAN PENGEMBANGAN KELOMPOK USAHA BERSAMA SEBAGAI UPAYA PENGENTASAN KEMISKINAN
}

\author{
Lalu Sarwan Hamit1, Muhamad Pradana Sasaka Aditya2, Lalu Dimas Dicky Iskandar3 \\ 1Fakultas Matematika dan IImu Pengetahuan Alam, Universitas Mataram, Mataram \\ 2Fakultas Pertanian, Universitas Mataram, Mataram \\ 3Fakultas Keguruan IImu Pendidikan, Universitas Mataram, Mataram \\ *Co-Author : lalusarwan.h8@gmail.com
}

\begin{abstract}
ABSTRAK. Kemiskinan merupakan problema kemanusiaan dunia yang menghambat kesejahteraan dan peradaban sehingga harus dan bisa ditanggulangi. Di Indonesia sendiri kemiskinan menjadi masalah yang dihadapi sejak dulu, dimana kemiskinan sendiri merupakan hal yang kompleks karena menyangkut berbagai macam aspek seperti hak untuk terpenuhinya pangan, kesehatan, pendidikan, pekerjaan dan sebagainya. Desa Montong Gamang yang merupakan salah satu desa di nusa tenggara barat yang menyumbangkan angka kemiskinan yang tinggi. Program ini dilaksanakan dengan berbagai kegiatan sosialisasi yang bermetode ceramah, tanya-jawab, dan diskusi yang bertujuan untuk membentuk, mengelola dan mengembangkan kelompok usaha bersama di Desa Montong Gamang. Dari hasil yang didapatkan, dapat terbentuk 27 kelompok usaha bersama yang telah tersusun rencana pengelolaan dan pengembangan kedapan yang dibantu oleh pemerintah desa melaui Badan Usaha Milik Desa (BUMDes). Melalui kelompok usaha bersama ini diharapkan dapat mampu mencukupi kebutuhan keseharian keluarga anggota masing-masing kelompok usaha bersama, hingga dapat mampu untuk dikembangkan menjadi usaha yang lebih besar.
\end{abstract}

Kata Kunci: Kemiskinan, Kelompok Usaha Bersama, Montong Gamang.

ABSTRACT. Poverty is a problem of world humanity that impedes prosperity prosperity and civilization so it must and can be overcome. In Indonesia, poverty is a problem that has always been faced, where poverty itself is a complex thing because it involves various aspects such as the right to fulfill food, health, education, employment. Montong Gamang Village is one of the villages in West Nusa Tenggara that contributed to high poverty rates. This program is carried out with socialization and discussion activities aimed at forming, managing and developing business groups in the village of Montong Gamang. From the results obtained, 27 business groups that have been formed in the management and development plan that have been assisted by the village government through the Badan Usaha Milik Desa (BUMDes). Through this business group is expected to be able to meet the daily needs of the family members of each business group, so that it can be able to be developed into a larger business.

Keyword: Poverty, Business Group, Montong Gamang 


\section{PENDAHULUAN}

Kemiskinan merupakan masalah yang dihadapi dan menjadi perhatian dunia hingga saat ini. Meskipun dalam tingkatan yang berbeda, tidak ada satupun negara di dunia ini yang dinyatakan kebal terhadap kemiskinan. Semua negara di dunia ini sepakat bahwa kemiskinan merupakan problema kemanusiaan yang menghambat kesejahteraan dan berdaban sehingga harus dan bisa ditanggulangi. Di Indonesia sendiri kemiskinan menjadi masalah yang dihadapi sejak dulu, dimana kemiskinan sendiri merupakan hal yang kompleks karena menyangkut berbagai macam aspek seperti hak untuk terpenuhinya pangan, kesehatan, pendidikan, pekerjaan dan sebagainya.

Berdasarkan data yang dihimpun oleh Badan Pusat Statistik pada bulan Maret 2019 tercatat bahwa penduduk miskin Indonesia bearada pada angka $9.41 \%$ atau tepatnya 25.14 juta penduduk. Angka ini menunjukkan tingginya kemiskinan di Indonesia. Sebaran kemiskinan di Indonesia tersebar pada tiap-tiap provinsi dengan tingkat yang berbeda-beda. Salah satu provinsi dengan tingkat kemiskinan yang cukup tinggi di Indonesia yaitu provinsi Nusa Tenggara Barat, dimana Nusa Tenggara Barat menempati delapan besar provinsi denga tingkat kemiskinan tertinggi di Indonesia. Nusa Tenggara Barat tecatat memiliki penduduk miskin sebesar $14.56 \%$ dari total penduduk atau tepatnya 736.96 ribu penduduk. Angka ini tersebar pada tiap tiap wilayah di Nusa Tenggara Barat.

Salah satu desa di Provinsi nusa tenggara barat yang tercatat memiliki tingkat kemiskinan yang tinggi yaitu Desa Montong Gamang, Desa Montong Gamang sendiri merupakan salah satu desa yang ada di Kecamatan Kopang Kabupaten Lombok Tengah dengan jumlah angka kemiskinan 23\% dari total 13.280 jiwa penduduk atau tepatnya terdapat 2.950 penduduk miskin. Melihat angka kemiskinan yang cukup tinggi di Desa Montong Gamang, perlu di dilakukan upaya untuk menurunkan angka kemiskinan tersebut.

Melalui suatu program yang disusun ini yaitu dengan pemberdayaan masyarakat kurang mampu Desa Montong Gamang dalam pengelolaan dan pengembangan kelompok usaha bersama diharapkan sebagai salah satu upaya pengentasan kemiskinan.

\section{METODE}

Program pemberdayaan masyarakat kurang mampu Desa Montong Gamang dalam pengelolaan dan pengembangan kelompok usaha bersama ini dilaksanakan selama 45 hari, dimulai sejak tanggal 23 Desember 2019 sampai dengan 6 Februari 2020 di Desa Montong Gamang, Kecamatan Kopang, Kabupaten Lombok Tengah

Dalam pelaksanaannya program ini berkerjasama dengan Pemerintah Desa Montong Gamang dan Dinas Sosial Kabupaten Lombok Tengah.

Program ini bertujuan sebagai salah satu upaya dalam pengentasan kemiskinan, dimana dengan berlangsungnya program ini masyarakat yang tergabung dalam kelompok usaha bersama dapat mampu menenuhi kebutuhan keseharian keluarganya hingga dapat mampu menembangkan kelompok usaha bersamanya menjadi usaha yang lebih besar. Untuk mencapai tujuan tersebut, maka disusunlah kerangka kegiatan sebagai berikut

\section{Sosialisasi tentang kelompok usaha bersama}

Sosialisasi tentang kelompok usaha bersama dilakukan dengan mengundang para kepala dusun dan perwakilan masyarakat kurang mampu pada setiap dusun untuk menghadiri acara 
sisialisasi. Metode yang digunakan dalam sosialisasi ini yaitu ceramah dan diskusi, dimana metode ini dapat lebih mudah dipahami karena adanya timbal balik, dan selanjutnya diharapkan kepada para kepala dusun dan perwakilan untuk mensosialisasikan yang telah didapatkan pada masyarakat dusunnya.

\section{Pembentukan dan pengelolaan kelompok usaha bersama}

Pembentukan dan pengelolaan kelompok usaha bersama ini dilakukan dengan menghubungi dan mengunjungi setiap dusun dengan membahas sebagai berikut:

a. Pengumpulan data sosial ekonomi masyarakat setiap dusun, dilakukan dengan mengunjungi setiap dusun dan meakukan penggalian informasi tentang potensi kelompok usaha bersama masyarakat yang dapat dibentuk.

b. Diskusi penguatan dan pembentukan kelompok usaha bersama serta kepengurusan kelompok di setiap dusun yang terkonfirmasi berpotensi, bersama dengan masyarakat langsung dengan metode diskusi untuk pembentukan kelompok usaha bersama, terkait dengan bidang usaha, aturan awik-awik, produksi, pemasaran, dan lainya.

3. Sosialisasi manajemen usaha dalam pengelolaan dan pengembangan kelompok usaha bersama

Sosialisasi manejemen usaha dilakukan dengan mengundang setiap pengurus elompok usaha bersama yang telah terbentuk sebelumnya, dengan tujuan meningkatkan pemahaman manejemen usaha dalam kelompok usaha bersama masing-masing. Sosialisasi ini dilakukan dnegan metode ceramah dan diskusi mengenai manejemen usaha.

\section{Diskusi rencana pengembangan kelompok usaha bersama}

Bersama anggota kelompok dengan metode diskusi membahas tentang pengembangan usaha dan inovasi peroduk, pemasaran dan sebagainya tentang bidang usaha masng-masing kelompok.

Selain itu, diskusi rencana keberlanjutan dan pengembangan kelompok usaha bersama dilakukan bersama dengan kepala desa, pengurus Badan Usaha Milik Desa (BUMDes), dan pengurus kelompok usaha bersama yang telah terbentuk dengan untuk mecapai kesepakatan keberlanjutan kelompok usaha bersama, dimana diharapkan keikutsertaan desa dalam pengembangan kelompok usaha bersama ini.

\section{HASIL DAN PEMBAHASAN}

Program pemberdayaan masyarakat kurang mampu Desa Montong Gamang dalam pengelolaan dan pengembangan kelompok usaha bersama ini terlaksana secara terstruktur dengan waktu yang tepat serta dengan antusiasme dan partisipasi masyarakat yang tinggi. Dibuktikan dengan baiknya sambutan masyarakat setaip dusun dalam kunjungan diskusi yang dilakukan, serta banyaknya masyarakat yang mengadiri setiap acara sosialisasi yang dilakukan.

\section{Sosialisasi tentang kelompok usaha bersama}

Sosialisasi tentang kelompok usaha bersama terlaksana pada tanggal 6 januari 2020, bertempat di Aula Kantor Desa Montong Gamang, dengan dihadiri oleh 31 masyarakat dari ketujuh belas dusun yang ada di Desa Montong Gamang. 


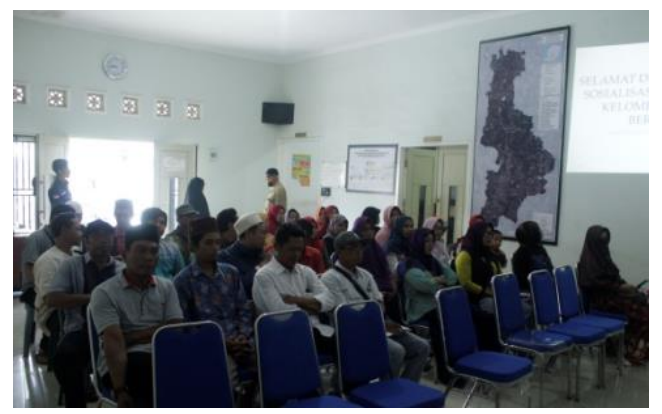

Gambar 1. Sosialisasi kelompok usaha bersama

Para peserta sosialisasi memiliki kemauan yang besar untuk mendapatkan informasi tentang kelompok usaha bersama dibuktikan dengan aktifnya para peserta dalam sesi duskusi yang ada.

\section{Pembentukan dan pengelolaan kelompok usaha bersama}

Pada pembentukan dan pengelolaan kelompok usaha bersama ini berlangsung dengan lancar, dimana dimulai dari pengumpulan data sosial ekonomi masyarakat setiap dusun untuk mendapatkan potensi kelompok usaha bersama yang ada.

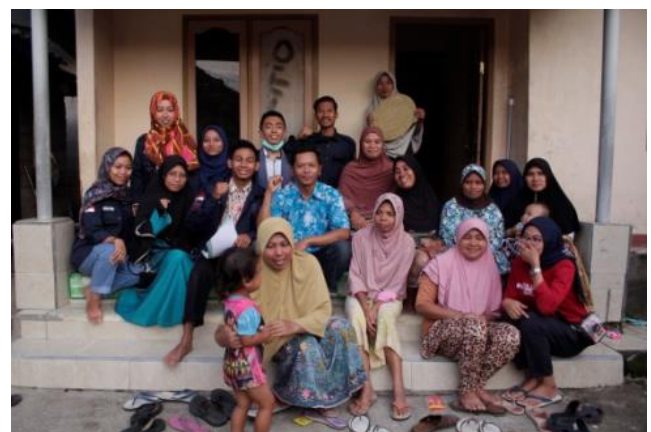

Gambar 2. Kegiatan diskusi pembentukan kelompok usaha bersama di Dusun Penimpoh

Pada keseluruhan dusun Desa Montong Gamang diperoleh potensi kelompok usaha bersama yaitu 27 kelompok usaha bersama dengan bidang usaha yang cukup beragam, dengan sebaran bidang usaha yaitu 14 usaha anyama ketak, 5 usaha pandai besi, 2 usaha produk bakul, 2 usaha bakulan, 1 usaha barang bekas, 1 usaha kudapan, 1 usaha kerupuk, dan 1 usaha kerajinan bambu.

\section{Sosialisasi manajemen usaha dalam pengelolaan dan pengembangan kelompok usaha bersama}

Sosialisasi manejemen usaha terlaksana pada tanggal 27 Januari 2020 di Aula Kantor Desa Montong Gamang. Dihadiri oleh 40 masyarakat dari masing-masing kelompok usaha bersama yang telah terbentuk. 
Gambar 3.

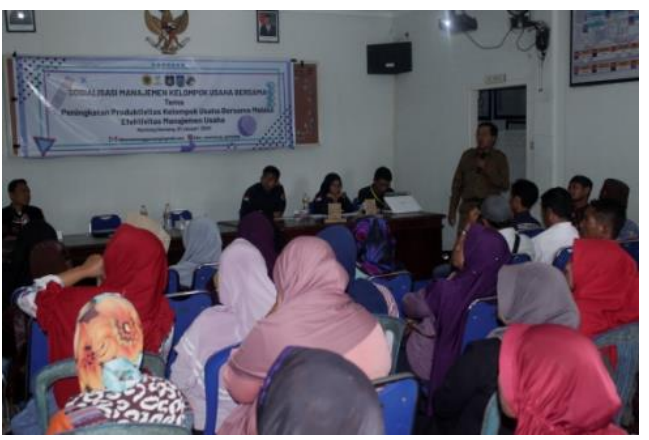

Sosialisasi manajemen usaha

Para peserta sosialisasi memiliki kemauan yang besar untuk mendapatkan ilmu yang lebih tentang manejemen usaha.

\section{Diskusi rencana pengembangan kelompok usaha bersama}

Pada hasil diskusi bersama masing-masing kelompok usaha bersama, didapatkan banyaknya produk inovasi pada produk kelompok usaha anyaman ketak, perbaikan kemasan bagi kelompok usaha bersama bidang kerupuk, dan pembahasan rencana perluasan pemasaran yang dilakukan di masing-masing kelompok usaha bersama. Selain itu dalam upaya pengembangan usaha bersama ini disepakati untuk membuat proposal permohonan bantuan modal yang ditujukan kepada dinas sosisal.

Pada hasil diskusi rencana penegembangan kelompok usaha bersama dengan kepala desa, BUMDes, dan perwakilan pengurus kelompok, pihak desa melalui BUMDes menyiapkan upaaya pengembangan kelompok usaha bersama yang telah terbentuk dengan membantu dalam pengelolaan pemasaran secara online dengan membentuk marketplace untuk memasarkan produk kelompok usaha bersama yang ada dengan dikelola oleh pengurus BUMDes Desa Montong Gamang.

Program pemberdayaan masyarakat kurang mampu Desa Montong Gamang dalam pengelolaan dan pengembangan kelompok usaha bersama secara keseluruhan berjalan dengan lancar, dan disertai dengan antusiasme masyarakat yang tinggi sehingga dapat terbentuknya 27 kelompok usaha bersama yang selanjutnya untuk dikelola dan dikembangkan sesuai dengan rencana yang telah disepakati.

Setelah terbentuknya kelompok usaha bersama ini, diharapkan masyarakat anggota kelompok usaha bersama ini mampu mencukupi kebutuhan keseharian keluarganya sehingga dapat mengurangi angka kemiskinan, serta diharapkan untuk dapat mampu mengembangkan kelompok usaha bersama tersebut. .

\section{KESIMPULAN}

Kemiskinan merupakan permasalahan kemanusiaan yang menghambat kesejahteraan dan berdaban sehingga harus dan bisa ditanggulangi. Kelompok usaha bersama merupakan salah satu program pengentasan kemiskinan. Melalui program ini, di Desa Montong Gamang telah terbentuk 27 kelompok usaha bersama yang dikelola secara bersama dan dengan bantuan dari pemerintah desa yang diharapkan mampu memenuhi kebutuhan keseharian keluarga anggota kelompok usaha bersama dan dapat mampu mengembangkan usaha bidang usaha tersebut. 
Sebagai saran dalam pembentukan, pengelolaan, dan pengembangan kelompok usaha bersama, diperlukan komunikasi yang terus menerus antar sesama anggota kelompok sehingga mengurangi permasalahan dapat timbul dalam kelompok. .

\section{REFERENSI}

Badan Pusat Statistik Nasional. 2019. Data Survei Sosial Ekonomi Nasional. Badan Pusat Statistik .

Badan Pusat Statistik NTB. 2018. Provinsi Nusa Tenggara Barat dalam Angka 2016. Badan Pusat Statistik NTB.

Pemerintah Desa Montong Gamang. 2019. Profil Desa Montong Gamang 2019. Kantor Desa Montong Gamang Kecamatann Kopang Kabupaten Lombok Tengah Nusa Tenggara Barat. 